\title{
Tänapäeva etnilised naljad eesti ja valgevene internetis
}

\author{
LIISI LAINESTE, ANASTASIYA FIADOTAVA
}

Rahvusnaljad on läbi aegade olnud populaarsed: väidetakse isegi, et need on sageduselt kolmandal kohal pärast suhte- ja poliitikateemalisi anekdoote (vt Shifman 2007: 198). Etnilist huumorit peetakse konteksti- ja kultuuritundlikuks, st teatud naljad levivad vaid teatud gruppide hulgas, samal ajal kui teised naljateemad - seks, poliitika, elukutsed - on universaalsemad ning levivad globaalselt. Christie Davies (1990) on seda põhjendanud naljategelase valiku sõltuvusega nalja rääkija ja sihtmärgi kultuurilistest ja ajaloolistest suhetest. Daviese väide ei pruugi tänapäeval enam kehtida, sest ideed ja stereotüübid levivad globaalses infovoos kiiremini ja kaugemale, jõudes ka nendeni, kes pole kõnealuse naljategelase ajaloo- ja kultuuritaustaga kursis. Naljad olenevad seega mitte enam nalja rääkija ja sihtmärgi suhetest, vaid pigem info liikumise ulatusest ja kiirusest. Koos globaliseerumisega kaovad naljadest vähehaaval etnilised määratlused, mis asendatakse üldisemate, universaalsemate määratlustega (vt ka Laineste 2008), näiteks naljadega programmeerijatest või politseinikest, interneti kasutamise praktikatest ja tagajärgedest. Naljades leiavad seega kasutamist teemad, mis riigiti ega grupiti palju ei erine (vt Laineste, Voolaid 2016). Võiks arvata, et etnilistest määratlustest hoidutakse seetõttugi, et ühiskondlikes hoiakutes tähtsustatakse senisest enam poliitilist korrektsust. See on seadnud rahvusnaljad ebasoodsasse valgusesse, osutades neile kui diskrimineerivatele ja ksenofoobsetele, olgugi et folkloorsetele narratiividele. Pidevalt mitmekesistuv ning aina tundlikum publik võib tõlgendada selliseid nalju rünnakuna ning nende kasutamist taunida.

Uurijad on leidnud, et etniliste pingete perioode saadab sageli etniliste naljade laine (Kuipers 2000: 149-150). Etniliste pingete suurenemine on seostatav viimasel aastakümnel mitmel pool päevakorda tõusnud sisserändeprobleemiga ning selle tagajärjel valjenenud paremäärmusliku retoorikaga, mille mõju on ilmne nii Euroopas kui ka mujal. Selle taustal näeme, et etniline huumor pole kadunud, kuid see on muutumas. Näiteks etnilisele kuuluvusele võidakse osutada mitte lihtsalt nimetades, vaid visuaalselt (Boxman-Shabtai, Shifman 2015), st välimuse või kommete kaudu, mis puudutavad söömist, riietust vm. Samuti varieeruvad ja vahetuvad kiiremini etnilise huumori sihtmärgid: naljarääkijad kasutavad vanades tuntud naljaskriptides uusi sihtmärke (Kuipers, Ent 2016), kellega nad rände ja globaliseerumise tingimustes kokku puutuvad. Ka etniline identiteet ise pole püsiv. Etnilist identiteeti on aina enam kirjeldatud selle muutlikkuse, katkendlikkuse ja paindlikkuse kaudu (vt Bianchini 2017 käsitlust voolava rahvusluse - ingl liquid nationalism - kohta). Peale selle on etniliste markerite kasutamine naljades tihedalt seotud identiteedi poliitiliste ja sotsiaalsete aspektidega: etniline määratlus osutab naljategelase sotsiaalsele staatusele ja poliitilistele seisukohtadele. 
Selles artiklis analüüsime kahe endise idabloki riigi - Eesti ja Valgevene - etnilise huumori arenguid tänapäeval. Nimetatud riikidel on arvestatav ajalooline ühisosa, mis väljendub nende pikaajalistes ning vastuolulistes suhetes geograafiliselt kõrval asetseva Venemaaga. Peamisteks erinevusteks on kuulumine eri keelkonda (soomeugri ja slaavi), mis mõjutab ka kultuuri, ning üldine poliitiline suunitlus ja kuuluvus maailmapoliitilistesse mõjualadesse (Euroopa Liit ning Sõltumatute Riikide Ühendus). Mõlemad autorid on varem uurinud etnilisi nalju Eesti ja Valgevene kultuuriruumis eraldi, analüüsides sotsiaalpoliitilise keskkonna mõju sisule ja vormile (Laineste 2008; Žvaleŭskaja 2013). Lähtuvalt võrdlev-ajaloolise meetodi seisukohtadest (Davies 1987, 1990 jj) annab sarnasuste ja erinevuste kirjeldamine infot mitte ainult võrreldavate kultuuride mõju kohta pärimusele, vaid huumori toimemehhanismide kohta üldiselt. Näiteks on samad kaugemad naljasihtmärgid - hiinlased, ameeriklased, mustanahalised jt -, seevastu lähedasemad sihtmärgid, nt venelased, on nii Eestis kui ka Valgevenes võrdselt populaarsed, kuid nende kohta käivad naljad kasutavad erinevaid skripte. ${ }^{1}$ Oluline on võrdlus seetõttugi, et arengud tänapäeva etnilises huumoris pole seni uurijate tähelepanu alla sattunud. Võrdluse tulemused laienevad ilmselt ka väljapoole uuritud naljapärimust, sest huumor, eriti pildiline huumor, on muutumas aina globaalsemaks. Mil määral esitatud järeldused väljaspool eesti ja valgevene naljatraditsioone paika peavad, seda näitavad edasised uurimused.

\section{Etnilised ja pseudoetnilised naljad}

Naljade ja nende sihtmärkide analüüsil toetume Christie Daviese etnilise huumori teooriale (raamatud aastatest 1990, 1998, 2002, 2011 ja mitmed artiklid 1987, 1991, 1999, 2003). Davies nimetab kolm keskset reeglit, mille järgi valitakse rumalusenaljade sihtmärke, st omistatakse teatud (etnilisele) grupile rumaluse skript: nalja peategelane on lähedal asuva, kuid marginaalse etnilise grupi esindaja; ta kõneleb nalja rääkijaga sarnast keelt; see, keda nali pilab, elab majanduslikult vähem arenenud ääremaal. Naljaskriptid ehk uskumuste ja stereotüüpide vastandpaaride komplektid (rumal-tark, arg-julge jms), mis nalja aluseks võetakse, on seotud grupivaheliste suhete iseloomu ja dünaamikaga. Naljateemade või -skriptide valikud sõltuvad ka nalja rääkijate kultuurilistest tõekspidamistest ja hoiakutest erinevate kaasaegse ühiskonna käitumispraktikate suhtes (näiteks isikliku hügieeni teemalised naljad, mida räägivad just need, kelle jaoks mustus on tabu; nt Kanada naljad newfoundlandlaste kohta, vt Davies 2002). Nalja rääkimine on enamasti asümmeetriline: vaid üks gruppidest on naljade sihtmärk (nt inglased räägivad nalju iirlastest, mitte vastupidi, vt Davies 1990: 11). Lisaks toimib vastuolu vaimse ja füüsilise vahel, st naljad sihivad gruppe, kelle jaoks füüsilisus on esiplaanil, eriti aga neid, kes idee poolest

\footnotetext{
${ }^{1}$ Skripti termini tõi huumoriuurimisse Victor Raskin (1985). Meie kasutame seda Arvo Krikmanni (2004) eeskujul, et tähistada kognitiivset tähendusvälja või seoste süsteemi, mis esindab inimese teadmust teatavate tegevuste ja situatsioonide kohta: mida inimesed teatud olukordades teevad, kuidas nad seda teevad, mis järjekorras jne (vt ka Krikmann 2002).
} 
peaksid esindama just vaimset maailma (nt vaimulikud, keda huvitavad liigselt maised lõbustused, vt Laineste jt 2019).

Victor Raskin (1985) on verbaalset huumorit ja selle lingvistilisi põhimehhanisme käsitlevas kaalukas teoses pühendanud peatüki ka etnilisele huumorile. Tema lähtepunktiks on tähelepanek, et etnilised anekdoodid põhinevad konventsionaalsetel, väljamõeldud ja müütilistel skriptidel nalja sihtmärgi kohta. Etniliste naljade hulka ei kuulu pseudoetnilised naljad, st sellised, mis seavad naljategelaseks mõne rahvuse esindaja, kuid mis ei ole seotud selle rahvuse kohta tavapäraselt kasutatud ja levinud naljaskriptidega. Raskini etniliste ja pseudoetniliste naljade eristus on huumoriuurijate hulgas rohkesti vastukaja leidnud; Raskinist inspireerituna defineerib ka Davies etnilist huumorit „eksitava loona, mis algab tõepäraselt ja peegeldab stereotüüpe tegelike etniliste gruppide kohta, kuid puändi ajal lülitub ümber ning esiplaanile ilmub absurdne, ebatõepärane skript" (Davies 1990: 320). Davies rõhutab, et etnilise nalja sihtmärgi võib edukalt vahetada uue vastu siis, kui naljaskriptid kattuvad arusaamadega, mis kuulajatel sihtmärgi kohta on. Nalja „kvaliteet” - mõistmine ja hinnang naljakusele - sellise vahetuse tõttu ei kannata. Raskin (1985: 207) aga väidab, et algse sihtmärgi asendamisel uuega on enamasti tulemuseks nn pseudoetniline nali, millega kaasneb ka nalja kvaliteedi langus.

Samas on nalju, kus etnilistele gruppidele omistatud naljaskript ei ole otseselt seotud kehtivate arvamustega selle grupi kohta või on väga üldine - st võib kehtida väga laialdaselt. Simon Weaver kutsub seda üldisemat ja seega problemaatilisemat gruppi mittestereotüüpseteks naljadeks, seades ühtlasi küsimärgi alla pseudoetniliste naljade mõiste, mis tema meelest ei arvesta naljarääkimise kontekstiga. Ta väidab, et „nalja tähendus konstrueeritakse mitte ainult skriptiopositsiooni põhjal, vaid kõikide naljas sisalduvate vihjete, väidete ja nende poolt esile kutsutud seoste koosmõjul" (Weaver 2011: 425). Aleksandar Takovski (2018) läheneb etnilise sihtmärgi vahetamisele teise nurga alt: ta toob sisse sellised mõisted nagu tõelised etnilised naljad versus funktsionaalsed etnilised naljad. Esimesed on seotud vaid konkreetsete etniliste gruppidega ning nende sihtmärk pole asendatav mõne teise grupi esindajaga (eelkõige keele- ja ajalooteemalised naljad). Teised on aga universaalsed (nt rumaluse või mustuse teemad) ning neid kasutatakse globaalselt ja kõikjal.

Giselinde Kuipers ja Barbara van der Ent on täheldanud, et etnilisi nalju ei saa enam lihtsalt kategoriseerida naljategelase etniliste tunnuste järgi ning igal grupil pole oma kindlaid, üksnes sellega seotud skripte. Vastupidi, iga grupi kohta käibib arvukalt erinevaid skripte ning need kanduvad ootamatu kergusega ühelt grupilt teisele. Kuipers ja Ent eristavad seejuures hoopis stereotüüpilisi nalju, mis vastavad kõige täpsemalt Raskini etniliste naljade kategooriale, ning hoiakulisi nalju. Viimased väljendavad üldistatud negatiivseid hoiakuid nalja sihtmärkide suhtes, neid kasutatakse mitmesuguste gruppide naeruvääristamiseks, naljade uutele sihtmärkidele kohandamine käib kiirelt, peegeldades muutusi ühiskonnas (nt vastukajana immigratsioonilainele). Nad osutavad, et naljad koonduvad ühe või mõne populaarsema sihtmärgi ümber ning nende liikumine sihtmärkide vahel osutab etniliste hierarhiate muutustele. Hollandi näitel kirjeldavad nad, kuidas vastsed immigrandid on naljades välja vahetanud varasemad, Hollandis juba 
kanda kinnitanud etnilised grupid, aga ka varem levinud (sh regionaalsed) naljategelased. Naljad, mis osutavad füüsilistele omadustele, nt nahavärvile, on samal ajal stabiilsemad, sest on seotud reaalsete ja nähtavate, mitte sihtgrupile omistatud ning fiktiivsete omadustega. See on oluline tähelepanek visuaalse huumori kontekstis, kus välimust vm äratuntavaid füüsilisi elemente kasutatakse sageli etniliste gruppide identifitseerimiseks. Mittenähtavaid omadusi kuvatakse samuti, kuid see on keerulisem ning tulemus mitmeti mõistetav. Etnilise huumori muutlikud ja hägusad piirid tingib tänapäeva ühiskonna sotsiaalne reaalsus: etniline määratlus nii igapäevaelus kui ka naljades on keerulisem ja mitmetahulisem kui varem. (Kuipers, Ent 2016: 613-614, 618)

Nimetatud väited tuginevad uurimustele, mis analüüsivad sõnalisi etnilisi nalju, st anekdoote. Võime oletada, et uued (visuaalsed ja audiovisuaalsed) huumorivormid, mis levivad internetis, võivad veelgi seniseid kategooriaid ja definitsioone mõjutada ning nõuda uut lähenemist etnilise huumori analüüsile.

Iisraeli teadlaste humoorika sisuga elektronkirjamanuste uurimus võttis vaatluse alla muutused, mis on toimunud seoses huumori liikumisega digikeskkonda. Lillian Boxman-Shabtai ja Limor Shifman (2015) osutasid, et mittekohalikke nalja sihtmärke (nt hiinlasi iisraeli naljades) kujutatakse peamiselt visuaalselt, samal ajal kui varem tuntud või kohalikke sihtmärke pilavad eelkõige verbaalsed naljad, sh anekdoodid. Stereotüübid tuntud sihtmärkide kohta on seejuures fikseeritud ja detailsemad, samal ajal kui mittekohalike sihtmärkide kirjeldus on üldistav ning umbmäärane. Sageli tuleb ette nn metanalju, kus naeruvääristatakse mitte niivõrd (või mitte ainult) naljas nimetatud sihtmärki, vaid kõiki neid, kes stereotüüpe usuvad. Võistlevad tõlgendused ja erinevad metatekstid annavad tulemuseks intertekstuaalse, mitmekihilise teksti, mille tõlgendus sõltub nii kitsamast (esitus) kui ka laiemast (ühiskond) kontekstist. Boxman-Shabtai ja Shifman (2015) leidsid, et tänapäeva etniline huumor ei sea etnilisust esiplaanile: see võib olla taustal olemas, kuid ei mängi alati keskset rolli huumori tõlgendamisel ja hindamisel. Etnilise määratluse hägusus või isegi juhuslikkus seisneb lisaks eelnevale selles, et naljategelased ei etendagi neis alati etnilisi, vaid hoopis üldise rumaluse või veidrusega seotud stereotüüpe (vt nt Weaver 2011). Niisiis on sageli jäetud kuulajate otsustada, kas tegemist on etnilise naljaga või mitte, olgugi et etniline sihtmärk on naljas olemas.

Üldjoontes on varasemad uurimused ühel meelel selles, et etnilises huumoris peab olema nimetatud või muul moel osutatud vähemalt üks etnilise grupi esindaja, st sihtmärk. Mõned lisavad sellesse kategooriasse etnilis-religioossed ning rassilised grupid (vt Kuipers, Ent 2016: 608). Olulisim etnilise nalja tunnus näib olevat see, et etniline määratlus on nalja mõistmise juures vajalik, st sihtmärgi etniline kuuluvus pole vaid juhuslik element. Selle asendamine muu määratlusega („korstnapühkija”) teeb nalja vähem tähenduslikuks või lausa absurdseks. Sharon Lockyer ja Michael Pickering (2005) on väitnud, et etnilise huumori sisu ja eesmärk on globaliseerumise ja vahendusprotsesside paljususe ning intensiivistumise tõttu kaotanud selgepiirilisuse. Samad protsessid on mõjutanud ka etniliste naljade vormi, mis on muutunud universaalsemaks. Veelgi enam, kogu etnilise huumori kategooria on laialivalguvam ja hägusam kui varem (vt Krikmann 2006: 34). 
Siinseks eesmärgiks on kirjeldada, kuidas viimase aja globaalsed ja lokaalsed arengud on mõjutanud etniliste naljade populaarsust ning nende sisu ja vormi dünaamikat. Uurimuses otsime vastuseid järgmistele küsimustele:

- Millised on eesti ja valgevene tänapäevase etnilise huumori põhijooned?

- Kuidas mõjutab etnilise huumori loomist (sisu ja vormi) ning tarbimist internetikeskkonna visuaalsus?

- Milliseid järeldusi saab vaadeldud materjali põhjal teha nüüdisaegse etnilise huumori kui kategooria kohta ja kuidas see seostub teiste, piirnevate naljakategooriatega (nt poliitilise huumoriga)?

\section{Allikad ja meetod}

Etnilise huumori eesti materjal (u 500 anekdooti ja naljapilti) pärineb eestikeelsest internetist: meeldib.ee-st ja teistest eestikeelsetest „huumorikeskustest” (ingl humour hubs, Shifman 2007: 188), näiteks sotsiaalmeedia huumorigruppidest (Facebookis, Instagramis). Koolipärimuse kogumiskampaania (2018) käigus lisandus andmebaasi 43 etnilist nalja.

Valgevene andmestik sisaldab u 300 sõnalist ja pildilist nalja, mis koguti valgevene- ja venekeelsest internetist. Eelkõige on need pärit foorumitest - Тут говорят: свежий анекдот ('Siin räägitakse: värske anekdoot', vt talks.by), Любимые анекдоты ('Lemmikanekdoodid', vt forum.onliner.by) - ja sotsiaalmeediagruppidest, mida identifitseeritakse kui valgevene auditooriumile orienteeritud lehekülgi: Жарты па-беларуску ('Valgevene naljad', vt VKontakte: Zharty pa-belarusku), Жарты на мове ('Omakeelsed (valgevene) naljad', vt VKontakte: Zharty na move), Белорусские мемы ('Valgevene meemid', vt VKontakte: Belorusskije memy). Nii eesti kui ka valgevene materjal sisaldab trükis avaldatud allikaid (nt Kõlu 2015; Fiadosik 2005), mis valiti nende suure etniliste anekdootide osakaalu tõttu.

Näidete valikul käesolevasse artiklisse lähtusime soovist tutvustada lugejatele populaarsemaid ning iseloomulikumaid naljatekste ning -pilte, st näidete representatiivsusest, et näidata internetihuumori mitmekesisust ja osutada diakroonilisele mõõtmele, sh teatud teemade püsimisele või kohandamisele vastavalt sotsiaalsetele oludele ja naljarääkijate või -jagajate suhetele teiste etniliste gruppidega. Iseloomulikumate teemade kõrval (nt Valgevene sümbolina kartul ning kannatlikkus, Eesti sümbolina ilm või aeglus) pöörasime tähelepanu tavapärastele formaatidele või sellistele, mis on populaarsed teatud ajahetkel („riigipallid”, vt näited 10 ja 11). Valisime võimalikult erinevaid etnilisi sihtmärke (jagades need üldistatult - geograafilise läheduse alusel - nelja gruppi, vt graafikuid 1 ja 2), kuid pidasime silmas ka, et need sihtmärgid oleksid aktiivses kasutuses nii eesti kui ka valgevene naljapärimuses. Viimane tingimus võimaldas sisukamalt võrrelda nende kahe riigi (ning keele- ja kultuuriruumi) sarnasusi ja erinevusi.

Peamiste naljateemade ja sihtmärkide tuvastamiseks ning klassifitseerimiseks nüüdisaegses etnilises huumoris kasutasime kontentanalüüsi. Analüüsiosas võtsime arvesse ka sotsiaalset ja kultuurilist tausta, mis seletab huumori vormi, teemade ja 
sihtmärkide muutumist. Kuigi antud uurimuses toetume peamiselt kvalitatiivsele ja võrdlevale diakroonilisele analüüsile, kasutame ka kontentanalüüsil saadud statistilisi andmeid, et näidata etniliste sihtmärkide jaotust erinevatel perioodidel.

\section{Eesti ja valgevene etnilise huumori põhijooned}

Diakrooniline vaade eesti ja valgevene andmestikule osutab, et etniliste naljade sihtmärk valitakse aina kaugemalt: XIX sajandi lõpu ja XX sajandi alguse geograafiliselt lähedased sihtmärgid (eestlastele mulgid, setud, hiidlased, vt ka Remmel 2003; valgevenelastele мужык 'kohalik mees', маскаль 'moskoviit' jm) asendusid aja jooksul lähimate naabritega (venelased, seda eriti üleliidulises kontekstis) ja Euroopa rahvastega (nt kolme rahva naljades). Praeguseks on kohalikke naljategelasi vähem ja erinevate, geograafiliselt kaugemate etniliste tegelaste arv on kasvanud nii Eestis kui ka Valgevenes (vt Laineste, Fiadotava 2017). Oleme varem osutanud, et viimastel aastakümnetel on taas populaarseks saanud nõukogudeaegne naljatraditsioon ja näiteks Eestis on uuesti tekkinud huvi kohalike sihtmärkide ja enese pihta suunatud huumori vastu (Laineste, Fiadotava 2017: 106) ning Valgevenes on suurenenud huvi venelasi pilavate naljade vastu (mis võib olla paiguti enesekohane). Olles täiendanud tulemusi uusima materjaliga, peame käesolevas artiklis tõdema, et pigem on kasvav osakaal kaugemate sihtmärkide („Euroopa” ja „maailm”) lõikes, samal ajal kui kohalikud tegelased ei esine naljades enam nii aktiivselt (vt graafikuid 1 ja 2).

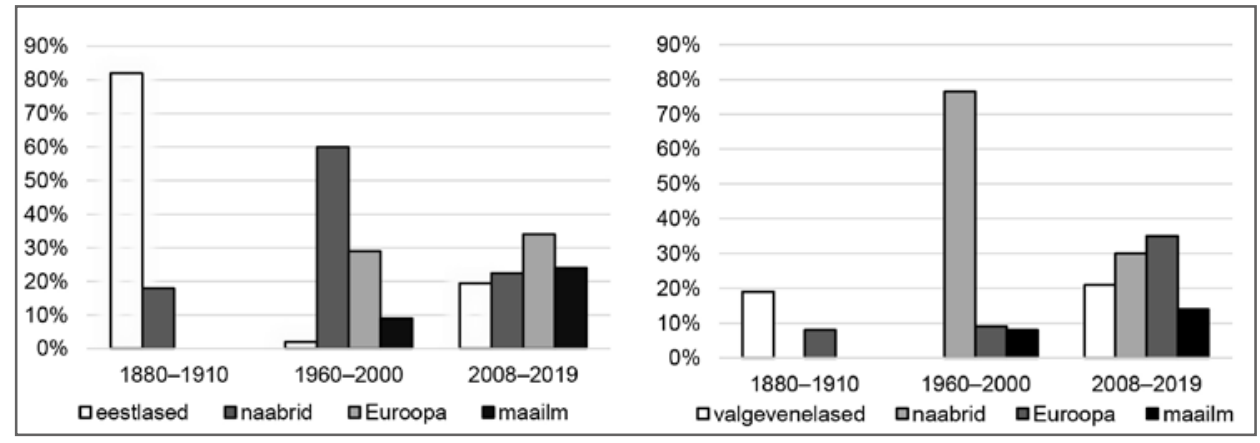

Graafik 1. Eesti etnilise huumori sihtmärkide osakaal kolme perioodi lõikes.

Graafik 2. Valgevene etnilise huumori sihtmärkide osakaal kolme perioodi lõikes.

Üldjoontes võib näha mõlemas huumoritraditsioonis geograafiliselt lähemate ja kaugemate sihtmärkide osakaalu kasvavat ühtlustumist. Pilkamiseks sobivad erinevad etnilised grupid ja naljarääkijate tähelepanu liigub kergesti ühelt teisele. Neljast jaotusest suurima kasvu on nüüdseks läbi teinud Euroopa sihtmärgid (sellised, kes pole naabrid, kuid kuuluvad samasse kultuuriruumi). Samal ajal on naljad naabrite kohta vähenenud nii Eestis kui ka Valgevenes, seda eelkõige viimasel perioodil, sest veel nõukogude ajal oli venelane nii eesti kui ka valgevene naljades 
sihtmärk number üks. Kohalike gruppide ja enesekohase huumori osakaal on tõusnud ja sagenenud on ka nalja heitmine kõige kaugemate sihtmärkide üle. Kas geograafiliselt kaugete sihtmärkide osakaal on veelgi tõusmas, peavad näitama jätkuuuringud: võimalik, et see kategooria on alles tõusuteel (vt ka Brzozowska, Chłopicki 2019: 239), kuid mitte veel populaarsuse tipus.

Järgnevas anname ülevaate eesti ja valgevene etnilisest huumorist XXI sajandil, järgides materjali esitamisel sihtmärkide valiku laienemist (kohalikud - naabrid Euroopa - maailm).

\section{Eesti ja valgevene huumor XXI sajandil: lokaalsest globaalseni}

\subsection{Kohalikud naljategelased}

Enesekohased etnilised naljad pilavad peategelast (eestlast või valgevenelast), kuid selle asemel et noomida või naeruvääristada, mainitakse gruppi iseloomustavat tunnust üsna neutraalsel viisil. Eelisseisu jääb nii mõnelgi juhul kohalik naljarääkija. ${ }^{2}$ Keskendume siinkohal kõige väljapaistvamale tunnusele: eestlaste naljades on selleks kinnisus ja valgevenelastel kannatlikkus.

(1) Kuidas tuvastada ekstravertset eestlast?

Ta vahib vestluse ajal oma jalanõude asemel sinu omi. (Kõlu 2015: 45)

Kannatlikkus võib osutada asjatule allaheitlikkusele, aga sellelegi, et rahvusel on salajased jõuvarud, mis aitavad rasketel aegadel toime tulla. Valgevenelased suudavad ellu jääda isegi sellistes absurdini viidud tingimustes, kus teised on elu kaotanud (surmateemalise absurdihuumori kohta vt Cohen 1999: 41):

(2) 'Koonduslaagris antakse teada: „Täna lähevad kõik gaasikambrisse!” Valgevenelane seisab rahvasummas ja mõtiskleb kurvalt: „Noh, jälle gaasikambrisse. Ja siis viiakse meid metsa, visatakse haisvasse hunnikusse, ja pärast pean ma pimedas teed otsima, et laagrisse tagasi jõuda!...”’3 (VKontakte: Padsluhana 2.0, 28. IX 2015)

Nimetatud skriptid on esindatud ka eesti ja valgevene visuaalses huumoris (meemides). Enesekohased meemid viitavad kohalikule sihtmärgile verbaalse vihje või nimetuse kaudu (näited 3-5, 7, 15) või visuaalselt (näited 6, 8, 10, 11). Kinnisust ja kannatlikkust on keeruline visuaalselt kujutada, mistõttu on see alati esindatud ka sõnaliselt ning pilt mängib toetavat rolli. Selleks sobib ka geneeriline kujutis, mis on pärit globaalselt meemiväljalt (näide 3).

\footnotetext{
${ }^{2}$ Kuipers ja Ent (2016: 628) osutavad, et hollandi naljades on hollandlased üldjuhul positiivsed tegelased: targad, töökad, ajaga kaasas käivad kodanikud.

${ }^{3}$ Siin ja edaspidi on autorite tõlge tähistatud ülakomadega.
} 
(3) 'Kui sa küsid eestlaselt, miks ta nii vaikne on: „Ma arvan, et pole mõtet raisata palju sõnu, kui asja saab aetud väheste sõnadega."' (Estonian moments, 14. IV 2013)

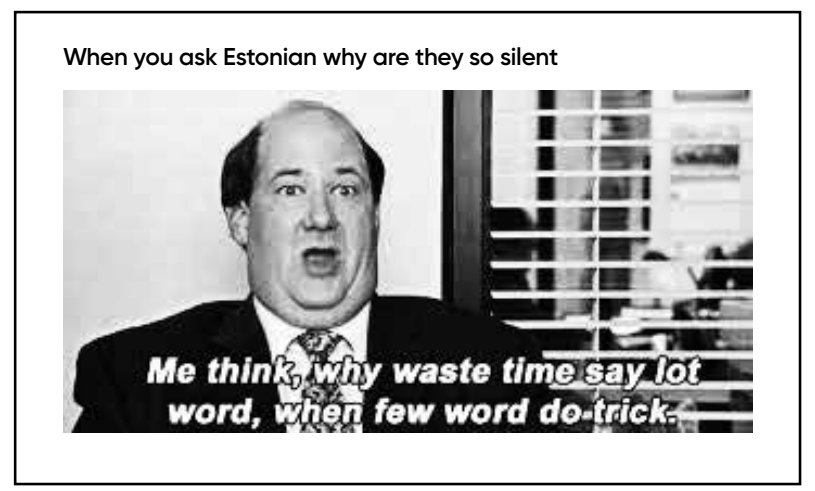

Kergesti visualiseeritavatest teemadest on eesti meemide hulgas levinuim ilma üle kurtmine; Valgevenes on selleks valgevenelaste väidetav kartulilembus, sh kartul kui Valgevene põhitoidus. Meemid pilavad eesti ja valgevene omapära, samal ajal kultiveerides ja kinnistades kujutatud arusaamu ja stereotüüpe. Toit on tavapärane etniliste naljade teema (vt Davies 2002; Kuipers 2000: 150), ilm seevastu on ebatavalisem, eriti kuna ilmaolud pole etniliselt määratletavad. Geograafilise ja etnilise valdkonna osalise kattumise tõttu on siiski tegu etnilise naljaga. Kuigi ilm on aktuaalne teema igal pool, on Eesti ilmal oma kindlad omadused, mida meemides ohtralt pilatakse (näited 4 ja 5).

(4) 'Vahepeal Kanadas Eestis: oktoober / aprill' (Naera pooleks, 5. V 2011)

(5) Eesti ilm (Facebook: eesti huumor, 13. III 2019)
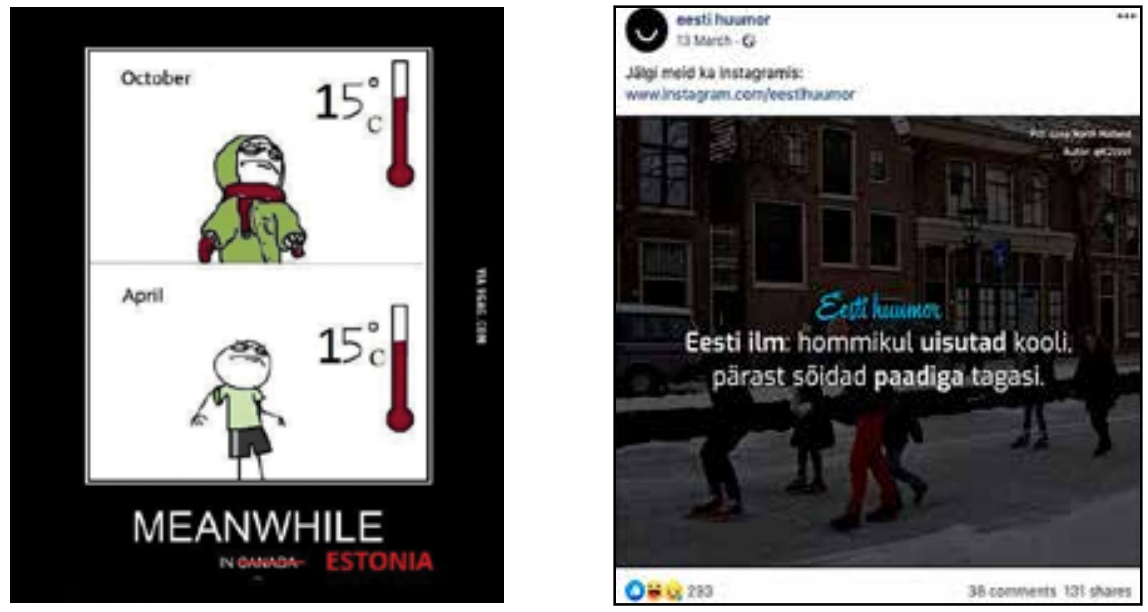
(6) Inglise keel $v s$ eesti keel (Delfi Kroonika: Igav, 28. XII 2014)

\begin{tabular}{|l|l|}
\hline English & Estonian \\
\hline Excuse me, may I disturb you for a second? & Kle... \\
\hline It's you! How lovely to see you! & Tsau! \\
\hline How are things with you? & Mis toimub? \\
\hline Excuse me, I didn't quite catch what you were saying? & Möh? \\
\hline Sorry for bumping into you like that. So terribly clumsy for me. & Ehh? \\
\hline
\end{tabular}

Valgevenelaste kartuliarmastus on levinud stereotüüp ja oluline identiteeditähis (Zadora 2019). Hüüdnimi бульбашь 'kartuliinimene' on valgevenelaste kohta kasutusel venelastel ja ka valgevenelastel endil (vt Bekus 2017: 253). Valgevene majanduses on põllundusel suur osatähtsus ning kartulit kasvatatakse seal palju: see on odav ja kasvab hästi. Samuti on see valgevene toitude oluline koostisosa. Seda stereotüüpi on edasi arendanud internetikasutajad, kelle jaoks kartul on muutunud Valgevene sümboliks: kartuli moodi on valgevenelaste jalajäljed (näide 7) ning ka miss Valgevene näeb välja nagu kartul (näide 8). Valgevene president Aliaksandr Lukašenka esineb meemides sageli kartulivõturiietes ja -mütsis (vt näiteid 9 ja 21), pildistatuna mitmesugustel põllumajanduslikel üritustel, millest ta sügiseti aktiivselt osa võtab.

(7) 'Meie teiega üritame täna tabada valgevenelast // Tema jäljed on mulla peal selgelt näha' (VKontakte: Belorusskije memy, 1. IV 2015)

(8) 'Miss Valgevene' (VKontakte: Belorusskije memy, 20. II 2015)
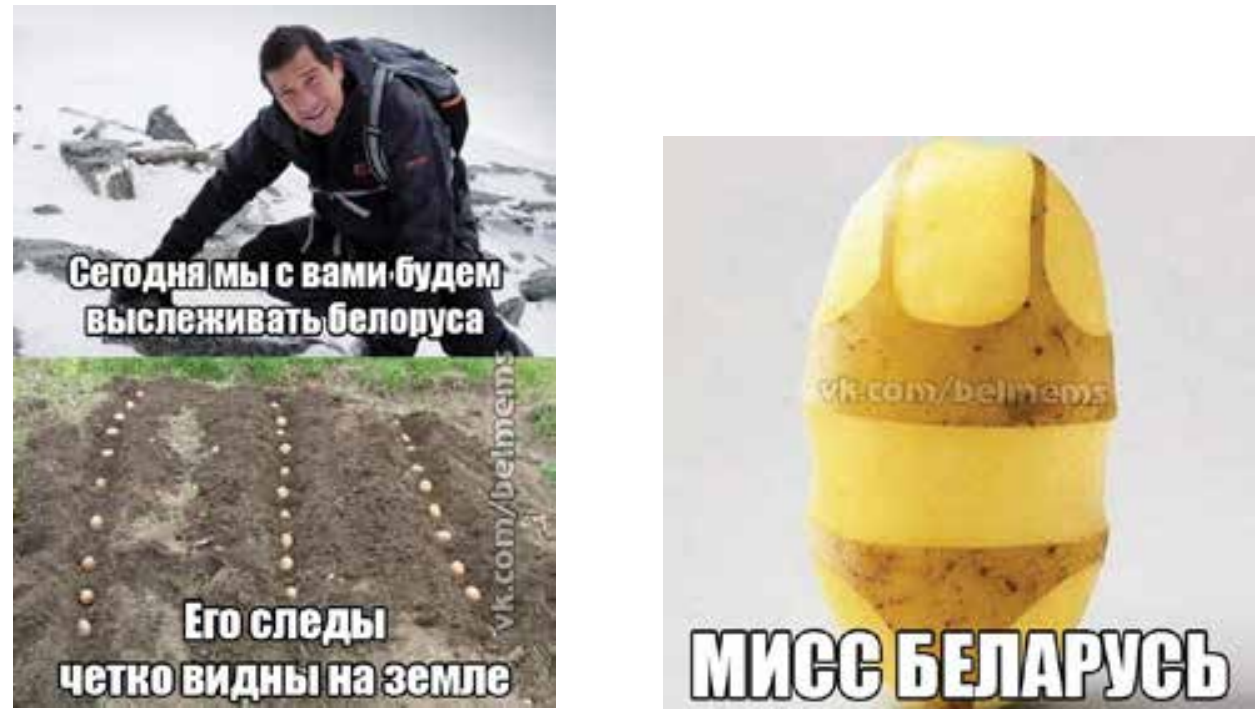
(9) 'Vabandage mind! Aga kas kartulitega oleks võimalik laenu tagasi maksta?' (VKontakte: Belorusskije memy, 18. VIII 2015)

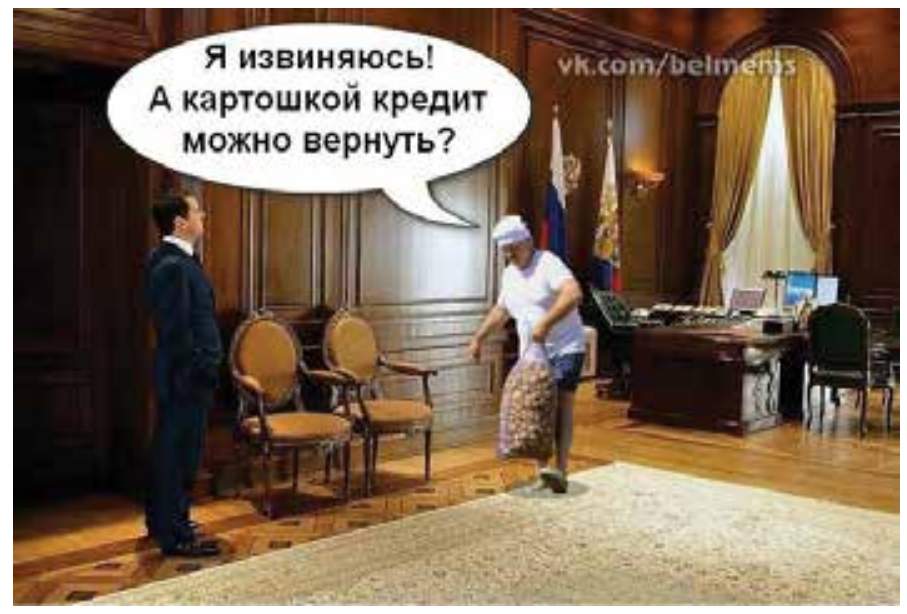

Kohalike etnilise huumori sihtmärkide pilamine kasutab enesekohaseid ja regionaalseid stereotüüpe. Eestlased ja valgevenelased pole üleilmselt tuntud naljategelased, kuid nende kohta käivates naljades on näha nii globaalseid elemente (näited 3, 4) kui ka kohalikke intertekstuaalseid vihjeid (näide 9), mis ühest küljest tutvustavad skripte kõrvalseisjatele, teisalt aga tuginevad märgisüsteemile, mis laiemale auditooriumile võib olla võõras ja seega mõistetamatu. Globaalsete elementidega meemides võib laenatud vorm hakata dikteerima meemi sisu, aga seejuures avardub võimalike seoste ja tõlgenduste hulk.

\section{2. "Meie ja naabrid": Eesti, Valgevene ja nendega piirnevad riigid}

Rumalusnaljades on tavaline, et sihtmärgiks valitakse lähinaaber, kellega naljarääkijal on tihedad suhted (Davies 1990 jj), või kohalik, kes asub naljarääkija suhtes perifeerses, marginaalses positsioonis (Kuipers, Ent 2016). Globaliseerumine on laiendanud etniliste sihtmärkide valikut geograafilisest lähipiirkonnast kaugemale, kuid lähinaabrid on siiski naljatraditsioonis jätkuvalt nähtaval kohal.

Asjakohaseks näiteks on nn riigipallid (ingl country balls): riigilipuvärvides joonistatud pallid, mis etendavad lähiriikidevahelisi suhteid ja ajalugu. Etnilise huumori uusvormid internetis esitavad vanu skripte uuel kujul (Chiaro 2018: 150), kasutades palju sellist, mida tunneme anekdootidest (näide 10).

(10) 'Tere, Läti! / Mul on sinu jaoks üks nali. // Ok // Kui palju lätlasi on vaja, et lambipirni vahetada? // Haha, ma arvan, et ainult ühte. // Ei, Läti, nelja! / Üks smugeldab Eestist lambipirni, üks annab piirivalvuritele altkäemaksu, üks maksab poliitbüroole, et see jurtat läbi ei otsiks, ja üks vahetab pirni. / Aga siis nad mõistavad, et Lätis pole elektrit. Ainult külm ja pime. // [Läti laseb Eesti maha]' (Picbear: @_switzerland_ball, 18. III 2018) 


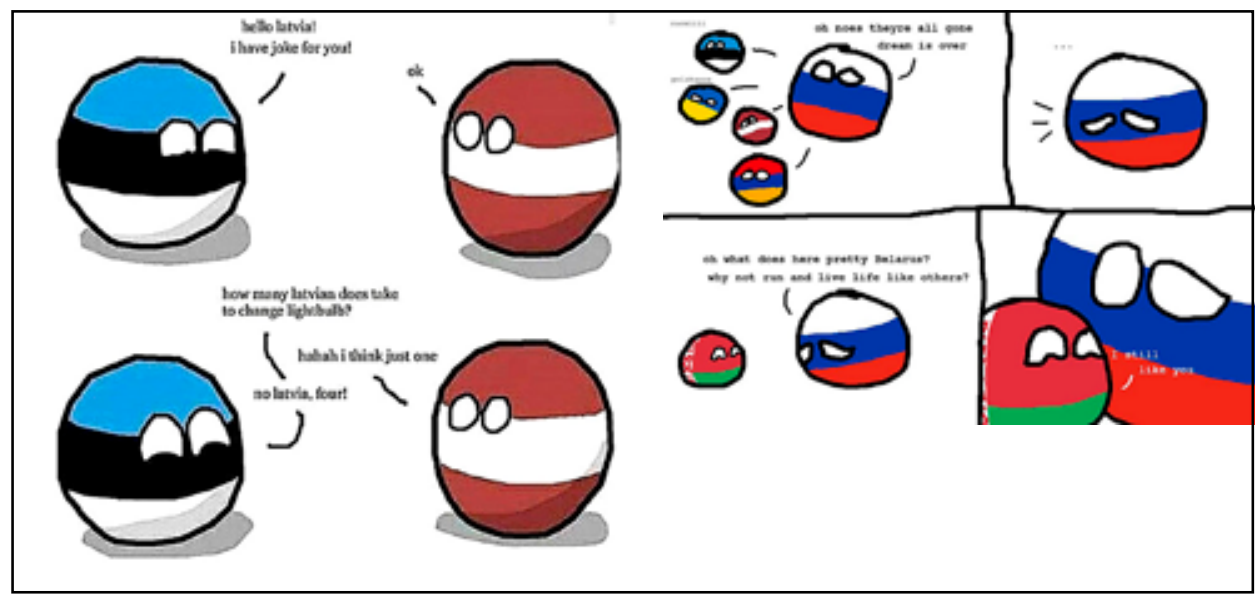

Näited 10 ja 11 osutavad, et mitte ainult etnilise huumori sisu ei ühtlustu, vaid ka vorm muutub sarnaseks. Oletatav auditoorium on samuti laiem, mistõttu korratakse lihtsalt mõistetavaid ja stereotüüpseid teemasid, nagu Eesti soov kuuluda Põhjamaade hulka või Valgevene kartulilembus. Nagu paljud teised tänapäevased etnilise huumori vormid, hõlmavad ka „riigipallid” poliitilist dimensiooni, näiteks illustreerides kohalike (näites 11 Venemaa ja Valgevene) geopoliitiliste suhete keerukust.

(11) 'Oh ei, nad on kõik läinud / unistus on läbi // ... // Oi, mida teeb siin ilus Valgevene? / Miks mitte joosta minema ja elada oma elu nagu teised? // Sa meeldid mulle ikka veel' (Polandball, 23. VII 2018)

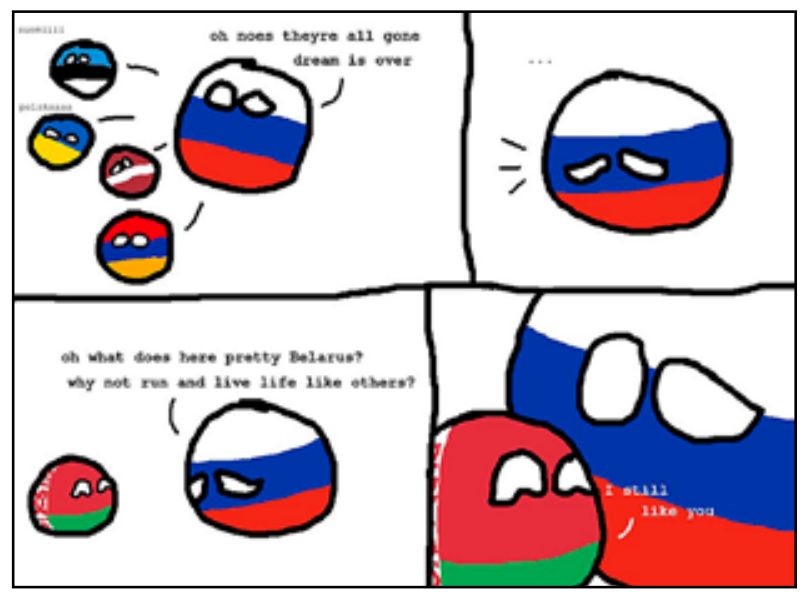

Eesti ja Valgevene ühine naaber ning ikka veel oluline huumori sihtmärk on Venemaa. Et see riik mängib globaalselt olulist, keskset rolli, samal ajal kui nii Eesti kui ka Valgevene on suhteliselt perifeersed, võib nende suhet näha tsentraalsuseperifeersuse teljel (vt Davies 1990: 43, 46). Venelaste kohta käivad naljad ei pila niivõrd üldist rumalust, kuivõrd spetsiifilisi stereotüüpe ja poliitilisi teemasid, nagu näites 12 . 
(12) Riia lennujaam:

- Nationality?

- Russian.

- Occupation?

- No, no, just visiting.

(VKontakte: Zharty pa-belarusku, 17. IV 2014; vt eesti versiooni Kõlu 2015: 174)

Kõige levinum venelaste kohta käibiv skript nii Eestis kui ka Valgevenes on liigne alkoholitarbimine. Seda kajastatakse nii sõnalises huumoris kui ka pildiliselt. Alkoholitarbimisel on mitmeid visuaalselt äratuntavaid sümboleid, millega vastavat skripti/kujutluspilti esile kutsuda. Nagu teised naljategelased, kellele heidetakse ette liigset joomist (nt iirlased, austraallased), joovad venelasedki avalikes kohtades ning kaotavad seejärel enesekontrolli (vt ka Davies 1998: 134):

(13) 'Egiptuse haid on palju näinud, aga purjus venelasi, kes kord karjusid: „Vau! Delfiinid!!!", kardavad nad seniajani' (VKontakte: Belaruski Gumar, 8. VI 2019)

(14) Joomingu Jumal Ivan (Facebook: Kreemised Meemid, 27. II 2017)

(15) 'Kui sa tahtsid Seitset Kuningriiki vallutada, aga need kuradi venelased tapsid sinu draakoni.' (VKontakte: Zharty na move, 29. VII 2017)
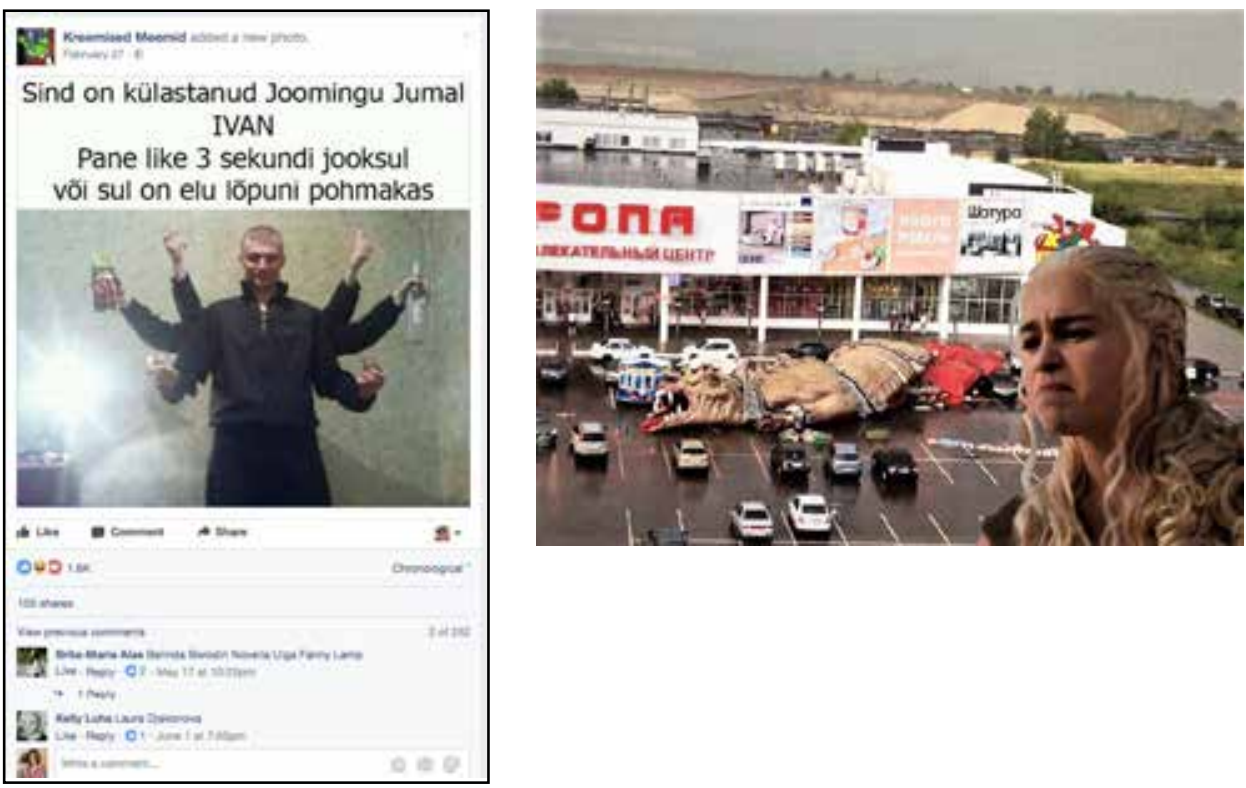

Vastupidiselt Daviese (1998: 101) tähelepanekule, et etnilised grupid, kes räägivad joomanalju, on ise alkoholitarbimises suhteliselt tagasihoidlikud, on nii Eestis kui ka Valgevenes liigjoomine probleemiks ning esineb teemana enesekohases huumoris. Joomisnaljade populaarsus ei seostu niisiis mitte niivõrd väärtuste vastuoluga, kuivõrd põhineb globaalsel (enese)stereotüübil venelaste kohta, kes on väidetavalt (ja uhkusega) suutelised palju alkoholi tarbima. 
Enamik venelasi pilavaid eesti ja valgevene nalju viitavad tuntud naljaskriptidele, kuid on nalju, mis kuuluvad Kuipersi ja Enti (2016) järgi hoiakunaljade kategooriasse ja mida Weaver (2011) liigitaks mittestereotüüpsete naljade alla. Venelased esindavad neis abstraktset kurjust või agressiivsust. Enamasti puudub sel juhul kontekstuaalne info sihtmärgi kohta ning venelase asemel võib tegelikult nalja sihtmärgiks olla mõni teine (etniline) tegelane, keda tajutakse nalja rääkijate suhtes vaenulikuna (näide 15).

Eelnevad näited 10-15 osutavad, et suhted naaberriikidega on sagedane etniliste naljade teema. Samal ajal on suur osa naabrihuumorist muutumas universaalseks nii sisult kui ka vormilt. See ei väljenda enam ei kehtivaid ega ka ajaloolisi võimuvõi tsentri ja perifeeria vahekordi. Etnilised naabrinaljad kasutavad ja kinnistavad globaalseid, universaalseid naljaskripte ning osutavad erinevatele, mitte ainult etnilisusest tõukuvatele aspektidele. Näiteks naljad venelaste kohta puudutavad sageli peale etnilise ka poliitilist ja sotsiaalset aspekti ning vormi osas kasutavad nii tuttavat anekdoodiformaati kui ka (audio)visuaalset meediumi.

\subsection{Poolkauged sihtmärgid ja mitme rahva naljad}

Nõukogude ajal algas geograafiliselt kaugemate naljategelaste intensiivsem levik ning näiteks Eestis suurenes võimalike sihtmärkide arv kahekordselt (Laineste 2008: 127). Uued sihtmärgid hõlmasid nii etnilisi gruppe Nõukogude Liidust (armeenlased, tšuktšid, grusiinid) kui ka väljastpoolt (hispaanlased, šotlased, rootslased). Üleliidulised sihtmärgid lisandusid ka valgevene huumoritraditsiooni. Laienev tegelasvalik lihtsustab uute naljategelaste kasutuselevõttu tänapäevalgi, sest paljud skriptid on juba eelnevalt tuttavad.

Mõned anekdoodivormid on väga pikaealised, näiteks anekdoodi kolmeastmeline ülesehitus (vt Berger 2016; Astapova 2015: 87). Naljad, kus omavahel võistlevad kolm rahvust, on levinud ka väljaspool Eestit ja Valgevenet, kuid tegelaste kombinatsioon on igal maal spetsiifiline: Eestis venelane, sakslane, eestlane (Tuisk 1995, 2010); Valgevenes sakslane, poolakas ja venelane või prantslane, inglane, venelane. Viimane tegelane on see, kes ütleb puändi ja „võidab”, isegi kui võit võib olla mitmemõtteline ning võitjast saab hoopis pilakangelane kõverpeeglis. Sageli ilmutavad tegelased väärloogikat, mis teeb kolme rahva naljad rumalusnaljade sarnasteks (näide 16).

(16) Eestlane, venelane ja sakslane on hiiglase juures vangis, aga et sealt välja pääseda, peavad nad ühe asja nii ära peitma, et hiiglane seda kätte ei saaks. Sakslane peidab oma kuldmündi hästi sügavale maapõue. Hiiglane otsib ja otsib, kuid saab kätte. Järg on venelase käes. Too viskab tühja viina pudeli sügavale ookeani. Hiiglane otsib ja otsib, kuid saab kätte.

Eestlane mõtleb tükk aega, mida teha. Lõpuks võtab kolmeliitrise purgi ja peeretab sinna sisse. Hiiglane võtab purgi ja nuusutab:

„Haisu tunnen küll aga kätte ei saa.”

Nii pääsesgi eestlane õnnelikult vangist. (Delfi naljad, 32082, 25. VII 2000) 
Kolme rahva nali võib väljendada ka spetsiifilist skripti (vt ka Goncharova, Khaleeva 2019: 132-133), mis on äratuntav naljarääkijate jaoks, nt valgevenelaste ärritav (peale)kaebamiskäitumine (näide 17).

(17) 'Nõukogude ajal saadeti enne väitekirja kaitsmist Moskvas asuvale Kõrgemale Atesteerimiskomisjonile alati midagi: Armeeniast väitekiri ja vagunitäis konjakit, Ukrainast - väitekiri ja vagunitäis soolapekki. Aga Valgevenest saadeti väitekiri ja vagunitäis kaebekirju.' (Brama mar, 12. VI 2010)

Etnilised naljad, mis loetlevad erinevaid rahvusi, kes kõik oma skripti järgi käituvad, said populaarseks XX sajandi lópupoole koos tegelasvaliku laienemisega geograafiliselt kaugematele piirkondadele. Sellise nalja mõistmine saab toimuda ainult siis, kui kuulajad on teadlikud viidatud skriptidest. Mitme rahva naljadel pole ühest sihtmärki: kõik on võrdsed ning puänt, kus üks naerualuseks tehakse, puudub (näide 18).

(18) PARADIIS ON SEAL, KUS

Politseinikud on inglased

Mehaanikud on sakslased

Kokad on prantslased

Armastajad on itaallased

Puberteedid on jaapanlased

Filme teevad ameeriklased

Naised on eestlased

Ja kogu üritus on korraldatud šveitslaste poolt

PÕRGU ON SEAL, KUS

Politseinikud on sakslased

Mehaanikud on prantslased

Kokad on inglased

Armastajad on šveitslased

Puberteedid on ameeriklased

Filme teevad jaapanlased

Naised on venelased

Ja kogu üritus on korraldatud itaallaste poolt.

(Delfi naljad, 32070, 15. VIII 2000; valgevene variant: E-reading.by)

Paljudes mitut rahvust visuaalselt kõrvutavates meemides on poliitiline sisu esiplaanil (vt näidet 19, mis vihjab 1994. aastast ametis olnud Valgevene presidendi Lukašenka autokraatsele valitsemisstiilile).

(19) 'Midagi moodsat. // Midagi moest läinut. // Aga midagi igavest.' (VKontakte: Belorusskije memy, 10. XI 2016) 


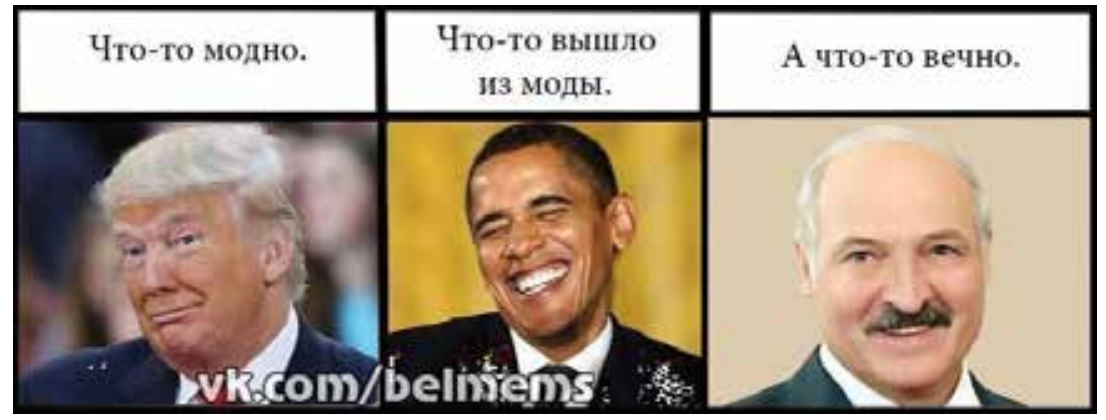

Nii kolme kui ka enama rahva naljades vastandatakse erinevaid etnilisi gruppe; seda saab teha ka visuaalselt. Sel juhul võib rahvusi esindada mõni tuntud motiiv (nt tuntud poliitik rahvuse esindajana, näide 20) või lipp (näited 10 ja 11). Need sümbolid või motiivid peavad nalja mõistmiseks seostuma skriptiga, mis käibib kujutatud rahvuse kohta. Näites 20 viidatakse jällegi valgevenelaste kartulilembusele, kuigi pildivalikus võib leida poliitilisi vihjeid.

(20) 'Vaenlane nr 1 USA-s // Vaenlane nr 1 Venemaal // Vaenlane nr 1 Valgevenes' (VKontakte: Belorusskije memy, 18. VI 2017)

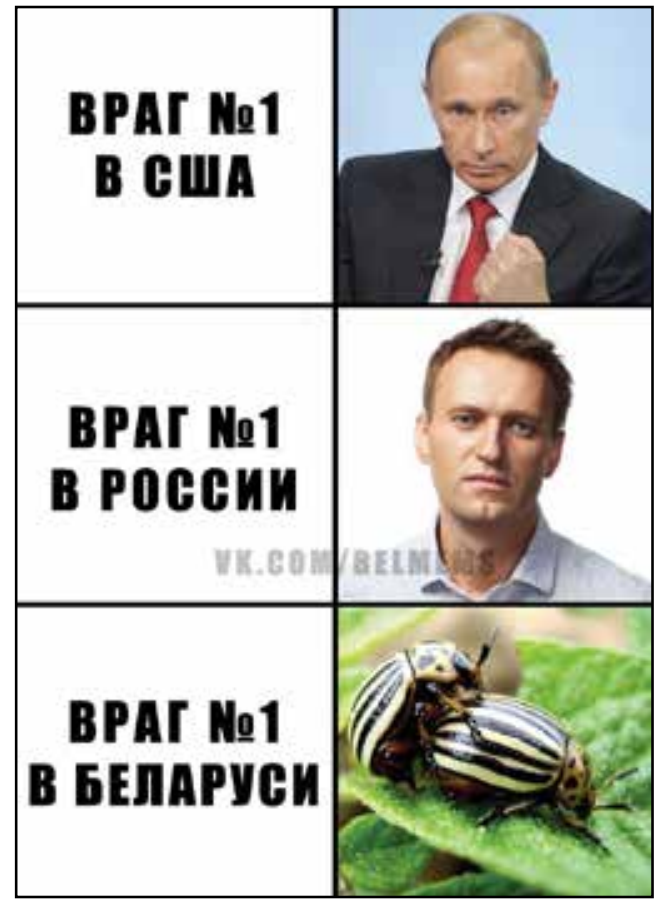




\subsection{Kauged sihtmärgid: hiinlased}

Etniliste gruppide kõrvutamine või vastandamine võib seega toimuda poliitikute sümbolina kasutamise kaudu. Mõnel juhul ei saa poliitikute huvisid või nende kohta käibivaid skripte laiendada kogu rahvusele (vt näidet 21: Putini kalastusoskused ja Trumpi naistemehekuulsus ei kirjelda venelasi või ameeriklasi üleüldiselt), kuid teistel juhtudel on see võimalik (näites 21 Lukašenka ja kartulid kui Valgevene sümbol, $\mathrm{Xi}$ Jinpingi pakkumises on viide Hiina ametlikule iibekontrollipoliitikale). Nagu ka näites 19, pole ükski riigijuht esile tõstetud kui huumori sihtmärk; selle asemel on tegelased esitatud üksteise kõrval ilma konkreetse puändita. Oluline on seegi, et tavapäraste valgevenelaste, venelaste ja veidi kaugemate ameeriklaste kõrvale on toodud üsna hiljutine etnilise huumori sihtmärk: hiinlased.

(21) 'Kuidas korraldada ideaalset piknikku:

Minu poolt lisandid // Ma püüan kala // Ma sebin tšikid // Ma toon preservatiive' (VKontakte: Belorusskije memy, 7. VIII 2017)

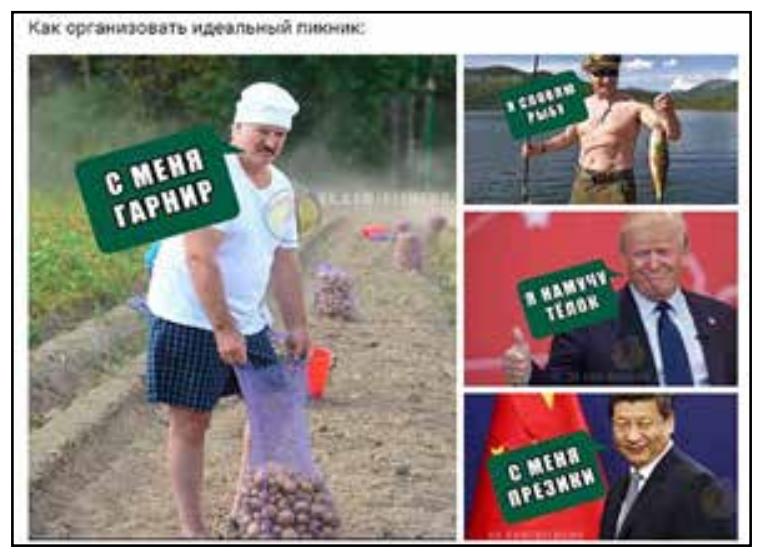

Hiinlaste suurenev kohalolu kõikidel elualadel, sealhulgas huumoris, on nii eesti kui ka valgevene naljatraditsiooni rikastanud uue sihtmärgiga. Hiinlaste kohta käiva huumori põhiskriptid puudutavad eelkõige kummalisi toitumisharjumusi, suurt rahvaarvu, tootmisjõudlust (vt Brzozowska, Chłopicki 2019). Nad moodustavad üldistatud kategooria koos paljude teiste idapoolsete rahvustega (jaapanlaste, korealaste jt), keda kujutatakse valdavalt sarnastena, sh visuaalses huumoris. Selline huumor pole enamasti üles ehitatud kohalike (eestlaste/valgevenelaste) ja võõraste (hiinlaste) kontrastile, pealegi on igapäevane kokkupuutumine nendega liiga harv, et selleks ainest anda. Vastupidi, sihtmärgiks olev hiinlane väljendab sellistes huumorinäidetes iseloomulikku omadust, mida omistatakse sellele rahvusele (ja nendega koos teistele asiaatidele). Mida kaugem etniline grupp, seda üldistatumad ja pealiskaudsemad on nende kohta käibivad naljaskriptid. Välimus on üks sellistest üldistest skriptidest, mis hiinlaste puhul domineerib - näiteks asiaatliku lõikega silmad (näide 22), teine sage skript puudutab veidrana näivaid toitumisharjumusi (näited 23, 24). 
(22) Kristlased räägivad: jumal avas meie silmad. Hiinlased ütlevad selle peale: meil ka. Pisut. (Delfi naljad, 31788, 16. I 2002)

(23) - Mida hiinlased söövad?

- ???

- Kõiki neljajalgseid, v.a. taburetid, ja kõiki roomajaid, v.a. linttraktorid.

(Viikberg 1997)

(24) Aadam ja Eeva (Kihulane)

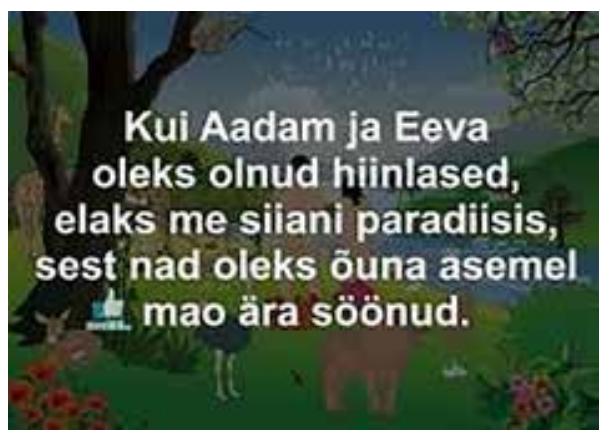

Hiinlaste suur rahvaarv ning tugev tööstusriigi maine (eriti mis puudutab kodutehnika ja elektroonika tootmist) on inspireerinud mitmeid meeme (näited 25 ja 26). Selline lähenemine võib lihtsalt kasutada või kinnitada käibivaid skripte (vt Ford 2015), kuid võib olla ka metakommentaar nalja auditooriumi ksenofoobsete stereotüüpide kohta.

(25) 'USA teatas, et boikotib 2008. aasta olümpiamänge Pekingis. Hiina vastas, et nad panevad ise USA meeskonna välja, ja kui vaja, saavad ka rahvastada terve Ameerika - jumal tänatud, neil elanikke jätkub.' (VKontakte: Zharty na move, 1. V 2016)

(26) 'Mikrohiinlased koostavad mikroprotsessorit' (VKontakte: Zharty na move, 28. VI 2016)

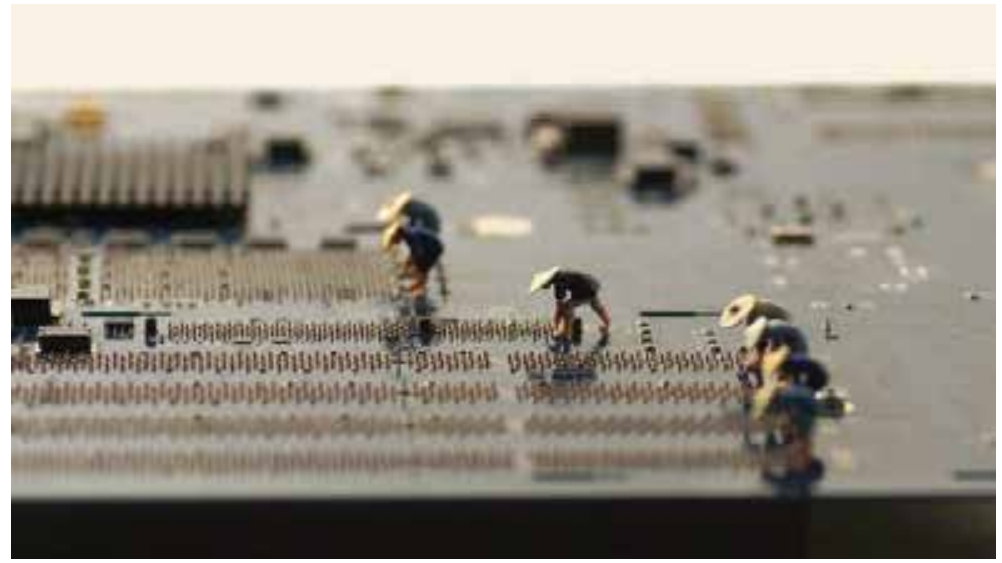


Kaugete sihtmärkide kujutamine (nagu osutavad siintoodud Hiina näited) põhineb tuntud, universaalsetel ja detailivaestel stereotüüpidel, näiteks etniliste tegelaste füüsilistel omadustel. Nad ei esine koos kohalike etniliste tegelastega, vaid tegutsevad anekdootides või meemides enamasti omaette (näited 24, 26; erandiks on näide 25). Nendega seotud naljad ja meemid on laenatud rahvusvahelisest praktikast. Geograafiliselt kaugel asetsevad etnilised grupid on nüüd nii Eestis kui ka Valgevenes suurema tähelepanu all kui enne 1990-ndaid (vt graafikuid 1 ja 2), ning tulevased uuringud peavad kindlaks tegema, kas see trend jätkub järgmistel aastakümnetel.

\section{Etniline huumor muutuste tuules}

Traditsioonide loomine ja muutumine on seotud igapäevaeluga ning seda mõjutava sotsiaalse ja poliitilise kontekstiga. Huumori põhirõhk on alati olnud teemadel, mis on olulised inimestele, kes nalju räägivad, kuid just seetõttu on naljarääkijate fookus läbi aegade pidevas muutumises. Etnilises huumoris avaldub see näiteks tegelaste valikus: lisaks kohalikele ja naabritele on tänapäeval sihtmärkideks kaugemad etnilised grupid, nt eesti ja valgevene naljades hiinlased. Põhijoonena eesti ja valgevene huumoripärimuses tuleb rõhutada erinevate, nii geograafiliselt lähedaste kui ka kaugete sihtmärkide võrdset pilkamist, millele osutab hiliseima perioodi etniliste sihtmärkide jaotus naljades (vt graafikuid 1 ja 2). Sarnasusele põhijoontes viitab ka eesti ja valgevene kaasaegse naljapärimuse temaatiline kattuvus, mis võib väljenduda lausa identsetes, ilmselt ingliskeelsest naljapärimusest tõlgitud tekstides (näide 18). Huumori sagenev tõlgitus ja vahendatus on seotud internetis pidevalt avarduvate meelelahutusvõimalustega. Teadmised (eelkõige kaugetest) etnilise huumori sihtmärkidest on pealiskaudsed ja põhinevad kuulujuttudel või loetud-kuuldud naljadel, mitte isiklikul kontaktil. Metahuumor (näide 27; vt ka Boxman-Shabtai, Shifman 2015) sisaldab kriitikat just sellise pealiskaudsuse kohta. Vahendatud huumori tarbimine süvendab oskust ja osavust naljaskriptide kasutamisel, kuid kõik vahendatud naljad ei pruugi pärast tõlkimist või kohandamist olla arusaadavad (näide 28; vt ka Raskin 1985: 206-207; Davies 1990: 320-321).

(27) Eestlane, venelane, blondiin, brünett, mustlane ja nunn lähevad baari.

Baarmen küsib: „Mis see on mingi nali või?” (Facebook: eesti huumor, 2. IX 2016)

(28) Kaks austraallast baaris:

- Ameerika õlu maitseb nagu seks kanuus.

- Miks nii?

- Veele nii kuradima lähedal. (Kõlu 2015: 37)

Näites 28 pole tegu niivõrd etnilise ja pseudoetnilise nalja vastandusega, kuivõrd tõlkeprobleemiga (huumori tõlkimisest vt Dore 2019), mis ei võimalda sõnamängu täielikult eestikeelsena korrata: eesti keeles puudub ingliskeelse originaali kahe- 
mõttelisus, kus õlle maitset ja kanuusõitu võib sama fraasiga kirjeldada (fucking close to water), ning samuti kaob puändist opositsioon 'seks / mitte seks'.

Mis puutub huumori sisu ja vormi muutustesse, siis lühike puändiga huumorivorm - anekdoot - sündis ajal, kui rahvanalja hakati levitama trükisõnas, näiteks ajalehtedes, ja tekkis vajadus millegi kompaktsema järele (Wickberg 1998; vt ka Kuipersi 2002 arutelu selle üle, millist mõju avaldas huumorile omakorda interneti levik). Anekdoodi kõrgaeg jäi eelmise sajandi teise poolde (Mesropova, Graham 2009; Lampland, Nadkarni 2016). Seoses sotsiaalmeedia võidukäiguga XXI sajandi alguses on tekstilise nalja kõrval tõusnud populaarseks visuaalne või multimodaalne huumoriformaat (vt ka Baran 2012). Hiiglaslikud anekdoodimaardlad (trükitud kogumikud, ajalehelisad, hiljem anekdoodisaidid internetis) on asendumas visuaalse huumoriga või sellisega, millel on peale verbaalse ka tugev visuaalne komponent. Neis huumorivormides on sisulisi kattuvusi, kuid vahel seab vorm piirid sisulegi, sest mõnda teemat on keerulisem visualiseerida. Seega võime väita, et internet ja sellega kaasnev visuaalsuse tõus on mõjutanud peale huumori vormi ka selle sisu.

Meie valimis on näited, kus visuaalne osa on võetud rahvusvahelisest meemivalikust (näide 3). Nii mõnedki visuaalse huumori vormid, nt demotivaatorid (humoorika või vastuolulise tekstiga täiendatud fotojäädvustused või -montaažid, vt Baran 2012: 175-176), toetuvad eelkõige sõnastusele ning visuaalne pool ei mängi huumori loomisel olulist osa. Meemides on üsna tavaline, et visuaalselt luuakse huumorile vaid meelelahutuslik või temaatiliselt seotud taust, kasutades selleks detaile, mis on olulised näiteks sihtmärgi äratundmisel (näites 26 kujutatud „mikrohiinlaste” mütsid). Samal ajal on pildi panus nalja õnnestumisse pigem tagasihoidlik. Nii võiks näites 21 asendada pildid poliitikute või riikide nimede, lippude vms-ga, ilma et nali muutuks. Väidame, et isegi kui visuaalne komponent pole huumori mõistmisel keskne või vajalik, on internetis jagatav huumor aina enam pildiline, sest veebisuhtlus on süvenevalt (audio)visuaalne, seda eriti sotsiaalmeedias (vt ka Highfield, Leaver 2016).

Kõik analüüsitud sihtmärkide grupid (kohalikud, naabrid, Euroopa ja ülejäänud maailm) on tänapäeval esindatud peale tekstilise huumori ka eesti ja valgevene visuaalses huumoris. Eesti meemides esinevad näiteks eestlased, lätlased, soomlased, moslemid, hiinlased; valgevene omades venelased, ukrainlased, ameeriklased, moslemid ja hiinlased (Laineste, Fiadotava 2017). Analüüsi tulemusel ilmnes, et visuaalses ja sõnalises huumoris tuleb esile erinevusi, mis ei puuduta ainult vormi, vaid ka sisu. Anekdoodid esitavad rahvusspetsiifilisi skripte (näited 1, 2, 12, 18), samas kui meemid väljendavad nii rahvusspetsiifilisi (näited 21, 24, 26) kui ka universaalsemaid huumoriskripte (näited 15,28). Peale selle esitavad anekdoodid skripte verbaalselt, samas kui meemides on skriptile viidatud nii sõnaliselt kui ka pildiliselt. Meemides ei pea sihtmärk olema nimetatud, sama hästi võib seda esitada tuntud sümbolite kaudu - lipu, toidu, joogi, riiete jm abil (näited 10, 11, 26). Visuaalsuse roll on etnilisuse esitamine ja esiletõstmine. Visuaalses huumoris on seetõttu piirid etnilise ja muude huumorikategooriate vahel veelgi hägusamad kui näiteks anekdootides, sest kõik sümbolid pole alati üheselt mõistetavad (Boxman-Shabtai, Shifman 2015: 532).

Muudatused huumoripärimuses puudutavad nii sisu kui ka vormi: sisus on lähedal elavad sihtmärgid vahetunud kaugemate vastu ja valikud ühtlustunud, 
sh naljaskriptid mitmekesistunud. Vorm on muutunud visuaalsemaks, esitades etnilisust toitumisharjumuste, välimuse vm kaudu. Kaugete sihtmärkide sagenemine on kaasa toonud tõlgitud ja vahendatud naljaskriptide leviku: nali ei põhine enam isiklikel kontaktidel naljategelastega. Eesti ja Valgevene materjalist nähtub, et globaalsed muutused - suurenenud liikuvus, laiendatud ligipääs rahvusvahelisele meediale, audiovisuaalse materjali suurenev osakaal internetis jms - on esile kutsunud või võimendanud tänapäeva huumori sisu ja vormi dünaamikas ning populaarsuses toimunud protsesse.

Kolmanda olulise tulemusena osutame, et etnilisust pole huumoris enam nii lihtne määratleda kui varem (kuigi aastakümneid tagasi arutleti samuti huumoriteoreetilises kirjanduses aktiivselt pseudoetnilise ja etnilise huumori erinevuste üle, vt Raskin 1985). Samamoodi ei piirdu etniline huumor enam ainult etniliste eripärade kommenteerimisega; lisanduvad ka sotsiaalsed ja poliitilised aspektid, mis on muutnud etnilise huumori kategooria piirid hägusamaks. Etnilisusest on mõnes näites saanud teisejärguline teema (ingl non-issue, vt Boxman-Shabtai, Shifman 2015; näide 19). Vahel ei kasuta anekdoodid ega meemid tuntud stereotüüpe; mõnel juhul on tegu üldistatud negatiivse suhtumisega sihtmärki (näide 15). Samas võib täheldada, et meemid kasutavad neutraalseid või isegi positiivseid stereotüüpe, nt valgevenelaste kartulilembus ei heida rahvusele negatiivset varju, kuigi esitab seda lihtsakoelise ja ruraalse ühiskonnana (näited 7-9). Sellega kaasnev hinnang sõltub auditooriumi tõekspidamistest ja väärtustest. Analüüsitud eesti ja valgevene andmestik sisaldab lähemal vaatlusel peale etnilise veel poliitilisi (näited 19-22), popkultuurilisi (näide 15) jm elemente. Verbaalsete ja visuaalsete vihjete kaudu osutatakse rahvustega lõdvalt seotud naljaskriptidele, mida võidakse kasutada ka metatasandil, st viidates mingile tuntud vormelile või varem kuuldud naljale. Etniline huumor võib samuti pilada rääkija ja tema auditooriumi jagatud ksenofoobseid arvamusi, muutudes seega metahuumoriks, mis naerab mitte niivõrd sihtmärgi kui nalja auditooriumi üle. Meie tulemused toetavad Boxman-Shabtai ja Shifmani (2015) tähelepanekut, et meemid ja muud huumorižanrid mängivad stereotüüpidega ning võivad nalja heita nii naljategelaste kui ka auditooriumi üle, kes selliseid stereotüüpe usuvad või toetavad (näide 27).

Etnilise huumori kategooria piiride ähmasus ja süvenev segunemine teiste kategooriatega ei puuduta ainult etnilist kategooriat ega ka mitte ainult huumorit. See on folklooris kajastuv üldisem suund, mida on kirjeldatud kui pidevat evolutsiooni (Brunvand 1972) ja loovuse väljendust (Stahl 1977). Liikuvus ja muutlikkus, mis sõltub igapäevaelu protsessidest ja rõhuasetustest, on folkloorse variatiivsuse tugisambaks, see on folkloorse pärimuse keskne tõsiasi (Toelken 1976: 10). Eriti kerkib see üsna ammune tähelepanek esile voolava modernsuse (ingl liquid modernity) ajastul (Bauman 2000), kus globaliseerumine pakub folklooriloojatele pidevat inspiratsiooni uueks vormiks ja sisuks, samal ajal ei ole autori identiteet folklooriloomise protsessis nii kesksel kohal kui varem. Etniline identiteet on vaid üks paljudest aspektidest enda koha ja rolli mõistmisel ning sellega seoses on see muutumas refleksiivseks ja pidevalt ümbermõtestatavaks elemendiks suuremas mustris. 
Artikli valmimist on toetanud Euroopa Liit Euroopa Regionaalarengu Fondi kaudu (Eesti-uuringute Tippkeskus), see on seotud Eesti Teadusagentuuri uurimisprojektiga IUT22-5 „Folkloori narratiivsed ja usundilised aspektid".

\section{VEEBIALLIKAD}

Brama mar. http://euga.livejournal.com

Delfi Kroonika: Igav. https://kroonika.delfi.ee

Delfi naljad = Eesti kaasaegsed anekdoodid. Koost Liisi Laineste, 2004. http://www.folklore. ee/ liisi/o2

E-reading.by $=$ Anekdoty o predstaviteljah raznyh nacional'nostej. [Анекдоты о представителях разных национальностей.] http://www.e-reading.by/bookreader.php/100319

Estonian moments. https://estonianmoments.tumblr.com

Facebook: eesti huumor. https://et-ee.facebook.com/eestihuumor

Facebook: Kreemised Meemid. https://www.facebook.com/KreemisedMeemid

Forum.onliner.by: Lyubimye anekdoty!!! [Любимые анекдоты!!!] https://forum.onliner.by/ viewtopic.php? $\mathrm{t}=14053 \&$ start $=1600$

Forum.onliner.by: Lyubimye anekdoty 2. [Любимые анекдоты 2.] https://forum.onliner.by/ viewtopic.php?t=735441\&start $=0$

Kihulane. https://kihulane.eu/

Meeldib.ee. http://meeldib.postimees.ee

Naera pooleks. https://naerapooleks.com

Picbear. https://www.picbear.org

Polandball. https://polandball.cc

Talks.by = Tut govorjat: svežij anekdot [Тут говорят: свежий анекдот.] https://talks.by/ showthread.php? $\mathrm{t}=2532253 \&$ page $=1$

Talks.by 2 = Tut govorjat: svežij anekdot-2 [Тут говорят: свежий анекдот-2.] https://talks. by/showthread.php?t=14265317\& page $=1$

VKontakte: Belaruski Gumar. [ВКонтакте: Беларускі гумар.] https://vk.com/belaruckigumar

VKontakte: Belorusskije memy. [ВКонтакте: Белорусские мемы.] https://vk.com/belmems

VKontakte: Padsluhana 2.0. [ВКонтакте: Падслухана 2.0.] https://vk.com/padsluchana

VKontakte: Zharty na move. [ВКонтакте: Жарты на мове.] https://vk.com/bel_zharty

VKontakte: Zharty pa-belarusku. [ВКонтакте: Жарты па-беларуску.] https://vk.com/bulbashorg

\section{KIRJANDUS}

Astapova, Anastasiya 2015. Why all dictators have moustaches: Political jokes in contemporary Belarus. - Humor. International Journal of Humor Research, kd 28, nr 1, lk 71-92.

Baran, Anneli 2012. Visual humour on the Internet. - Estonia and Poland: Creativity and Tradition in Cultural Communication. Kd 1: Jokes and Humour. Toim Liisi Laineste, Dorota Brzozowska, Władysław Chłopicki. Tartu: ELM Scholarly Press, lk 133-148.

Bauman, Zygmunt 2000. Liquid Modernity. Cambridge: Polity. 
Bekus, Nelly 2017. Constructed 'otherness'? Poland and the geopolitics of contested Belarusian identity. - Europe-Asia Studies, kd 69, nr 2, lk 242-261.

Berger, Arthur Asa 2016. Three holy men get haircuts: The semiotic analysis of a joke. Europe's Journal of Psychology, kd 12, nr 3, lk 489-497.

Bianchini, Stefano 2017. Liquid Nationalism and State Partitions in Europe. Cheltenham: Elgar.

Boxman-Shabtai, Lillian; Shifman, Limor 2015. When ethnic humor goes digital. - New Media \& Society, kd 17, $\mathrm{nr} 4, \mathrm{lk}$ 520-539.

Brzozowska, Dorota; Chłopicki, Władysław 2019. The Chinese as targets in Polish humorous discourse. - Humor. International Journal of Humor Research, kd 32, nr 2, lk 235-265.

Brunvand, Jan Harold 1972. The study of contemporary folklore: Jokes. - Fabula, kd 13, nr 1, lk 1-19.

Chiaro, Delia 2018. The Language of Jokes in the Digital Age. Oxon-New York: Routledge.

Cohen, Ted 1999. Jokes: Philosophical Thoughts on Joking Matters. Chicago-London: University of Chicago Press.

Davies, Christie 1987. Language, identity, and ethnic jokes about stupidity. - International Journal of the Sociology of Language, nr 65, lk 39-52.

Davies, Christie 1990. Ethnic Humour Around the World: A Comparative Analysis. Bloomington: Indiana University Press.

Davies, Christie 1991. Fooltowns: Traditional and modern, local, regional and ethnic jokes about stupidity. - Spoken in Jest. (The Folklore Society Mistletoe Series 21.) Toim Gillian Bennett. Sheffield: Sheffield Academic Press, lk 215-235.

Davies, Christie 1998. Jokes and Their Relations to the Society. Berlin-New York: Mouton de Gruyter.

Davies, Christie 1999. Change and continuity in one of Europe's oldest comic ethnic scripts. - Humor. International Journal of Humor Research, kd 12, nr 1, lk 1-31.

Davies, Christie 2002. The Mirth of Nations. New Brunswick: Transaction Publishers.

Davies, Christie 2003. Jokes that follow mass-mediated disasters in a global electronic age. - Of Corpse: Death and Humor in Folklore and Popular Culture. Toim Peter Narvaez. Logan: Utah State University Press, lk 15-34.

Davies, Christie 2011. Jokes and Targets. Bloomington: Indiana University Press.

Dore, Margherita (toim) 2019. Special Issue on Humour in Multimodal Translation. - European Journal of Humour Research, kd 7, nr 1.

Fiadosik, Anatol' (koost) 2005. Zharty, anekdoty, gumareski. 2. trükk. Minsk: Belaruskaya Navuka. [Анатоль С. Фядосік, Жарты, анекдоты, гумарэскі. Выданне 2. Мінск: Беларуская навука.]

Ford, Thomas (toim) 2015. Special Issue: The Social Consequences of Disparagement Humor. - Humor. International Journal of Humor Research, kd 28, nr 2.

Goncharova, Oxana; Khaleeva, Svetlana 2019. Stereotypes in jokes and anecdotes: The search for ethnic and national features. - Proceedings of the International Conference Topical Problems of Philology and Didactics: Interdisciplinary Approach in Humanities and Social Sciences, lk 128-133. (Advances in Social Science, Education and Humanities Research 312). 
Highfield, Tim; Leaver, Tama 2016. Instagrammatics and digital methods: Studying visual social media, from selfies and GIFs to memes and emoji. - Communication Research and Practice, kd 2, nr 1, lk 47-62.

Krikmann, Arvo 2002. Sissejuhatavat huumorist ja rahvanaljast: ained, mõisted, teooriad. Keel ja Kirjandus, nr 12, lk 833-847.

Krikmann, Arvo 2004. Koestler, Raskin, Attardo ja teised: lingvistiliste huumoriteooriate uuemaist arenguist. (Reetor 4.) Tartu: Eesti Kirjandusmuuseum.

Krikmann, Arvo 2006. Contemporary linguistic theories of humour. - Folklore: Electronic Journal of Folklore, kd 33, lk 27-58.

Kuipers, Giselinde 2000. The difference between a Surinamese and a Turk: Ethnic jokes and the position of ethnic minorities in the Netherlands. - Humor. International Journal of Humor Research, kd 13, nr 2, lk 141-176.

Kuipers, Giselinde 2002. Media culture and Internet disaster jokes: Bin Laden and the attack on the World Trade Center. - European Journal of Cultural Studies, kd 5, nr 4, lk 450-470.

Kuipers, Giselinde 2006. The social construction of digital danger: Debating, defusing and inflating the moral dangers of online humor and pornography in the Netherlands and the United States. - New Media \& Society, kd 8, nr 3, lk 379-400.

Kuipers, Giselinde; Ent, Barbara van der 2016. The seriousness of ethnic jokes: Ethnic humor and social change in the Netherlands, 1995-2012. - Humor. International Journal of Humor Research, kd 29, nr 4, lk 605-633.

Kõlu, Erkki 2015. Eestlane ja teised rahvad. 1457 anekdooti erinevatest rahvustest. Tallinn: Tänapäev.

Laineste, Liisi 2008. Post-socialist Jokes in Estonia: Continuity and Change. (Dissertationes folkloristicae Universitatis Tartuensis 12.) Tartu: Tartu University Press.

Laineste, Liisi; Fiadotava, Anastasiya 2017. Globalisation and ethnic jokes: A new look on an old tradition in Belarus and Estonia. - The European Journal of Humour Research, kd 5, nr 4, lk 85-111.

Laineste, Liisi; Fiadotava, Anastasiya, Jonuks, Tõnno 2019. Naljad kirikutegelastest Eestis ja Valgevenes XIX-XXI sajandil. - Keel ja Kirjandus, nr 12, lk 937-959.

Laineste, Liisi; Voolaid, Piret 2016. We Believe! Online representations of the Olympic winner as a mythic hero. - Folklore: Electronic Journal of Folklore, nr 54, 1k 9-38.

Lampland, Martha; Nadkarni, Maya 2016. „What happened to jokes?”: The shifting landscape of humor in Hungary. - East European Politics and Societies, kd 30, nr 2, lk 449-471.

Lockyer, Sharon; Pickering, Michael (toim) 2005. Beyond a Joke: The Limits of Humour. Hampshire-New York: Palgrave Macmillan.

Mesropova, Olga; Graham, Seth (toim) 2009. Uncensored? Reinventing Humor and Satire in Post-Soviet Russia. Bloomington: Slavica.

Raskin, Victor 1985. Semantic Mechanisms of Humor. Dordrecht: Reidel.

Remmel, Mari-Ann 2003. Viru mees viljapulli, Harju mees aganapulli. - Mäetagused, nr 21, lk 141-192.

Shifman, Limor 2007. Humor in the age of digital reproduction: Continuity and change in Internet-based comic texts. - International Journal of Communication, $\mathrm{kd} \mathrm{1,} \mathrm{nr} 1, \mathrm{lk}$ 187-209. 
Stahl, Sandra K. D. 1977. The personal narrative as folklore. - Journal of the Folklore Institute, kd 14, nr 1-2, lk 9-30.

Zadora, Anna 2019. Daily identity practices: Belarus and potato eaters. - Communist and Post-Communist Studies, kd 52, nr 2, lk 177-185.

Žvaleǔskaja, Anastasiya 2013. Spiecyfika vykarystannia etničnych žartaŭ u etnalahičnym dasliedavanni. - Pytanni mastactvaznaŭstva, etnalohii i faĺklarystyki. Kd 15. Toim A. I. Lakotka. Minsk: Prava i ekanomika, lk 281-285. [Анастасія Жвалеўская, Спецыфіка выкарыстання этнічных жартаў у этналагічным даследаванні. - Пытанні мастацтвазнаўства, этналогіi і фалькларыстыкі. Вып. 15. Рэд. А. І. Лакотка. Мінск: Права і эканоміка, 281-285.]

Takovski, Aleksandar 2018. Extending ethnic humour theory: Genuine vs. functional ethnic joke scripts. - European Journal of Humour Research, kd 6, nr 2, lk 60-80.

Toelken, Barre 1976. The Dynamics of Folklore. Boston: Houghton Mifflin Company.

Tuisk, Astrid 1995. Omast ja laenatust eesti laste kolme rahva anekdootides. - Lipitud-lapitud. (Tänapäeva folkloorist I.) Toim Mare Kõiva. Tartu: Eesti Kirjandusmuuseum, lk 71-82.

Tuisk, Astrid 2010. Kolme rahva anekdoodid lastepärimuses: viisteist aastat hiljem. - Tulnukad ja internetilapsed. Uurimusi laste- ja noortepärimusest. (Tänapäeva folkloorist VIII.) Toim Eda Kalmre. Tartu: EKM Teaduskirjastus, lk 163-186.

Viikberg, Jüri (koost) 1997. Anekdoodiraamat. Naeruga eilsest. Eesti anekdoot 1960-1990. Tallinn: Eesti Keele Sihtasutus.

Weaver, Simon 2011. Jokes, rhetoric and embodied racism: A rhetorical discourse analysis of the logics of racist jokes on the Internet. - Ethnicities, kd 11, nr 4, lk 413-435.

Wickberg, Daniel 1998. The Senses of Humour: Self and Laughter in Modern America. Ithaca, NY: Cornell University Press.

Liisi Laineste (snd 1978), PhD, Eesti Kirjandusmuuseumi folkloristika osakonna vanemteadur (Vanemuise 42, 51003 Tartu), liisi@folklore.ee

Anastasiya Fiadotava (snd 1991), MA, Tartu Ülikooli kultuuriteaduste instituudi doktorant; Eesti Kirjandusmuuseumi folkloristika osakonna nooremteadur (Vanemuise 42, 51003 Tartu), anastasiya.fiadotava@folklore.ee

\section{Contemporary Estonian and Belarusian ethnic jokes on the internet}

Keywords: joke, meme, ethnic humour, ethnic identity, Estonia, Belarus

Much of today's entertainment, including humor communication, takes place online. It can be expected that as a result of globalization, jokes will become more universal and, consequently, local distinctions, such as specific ethnic targets that have so far differed from region to region, will disappear. The popularity of ethnic jokes can also be influenced by the growing demand for political correctness. This article compares 
Estonian and Belarusian ethnic humor, focusing on the last few decades. The aim is to improve the understanding of the relationship between ethnic humor and social reality: to complement the models of target choice (Davies 1990,2002, 2011) and to describe the effects of globalization on the joke tradition. The three central research questions address the following issues:

- What are the main features and tendencies in contemporary Estonian and Belarusian ethnic jokes on the internet?

- How does the visuality of internet environment influence the creation (of both form and content), sharing and consumption of humour?

- What is the current status of the category of ethnic jokes?

The results of the article indicate that target choice depends less than before on the geographical proximity of the target group: close and distant targets are mocked increasingly equally. There are universal issues that are addressed similarly in Estonian and Belarusian internet humour.

Internet humour tends to be visual and often relies on language play. We claim that even though the visual component is not always central or necessary for getting the joke, much of the humour shared online is increasingly visual because of the nature of computer-mediated communication in general. This affects not only the form of shared humour but also its content: international joke templates get adapted more easily across cultures.

The category of ethnic humour has become more fluid and fuzzy and thus discussions about the ethnic versus pseudo-ethnic jokes can largely be discarded when talking about contemporary ethnic humour. Ethnic humour comments on ethnic, social and political characteristics of the target. Furthermore, some joke topics have developed into metajokes that do not make fun only (or primarily) of the joke targets but of the people who hold such stereotypes about these targets.

National and ethnic differences in humour production and evaluation are shifting as cultural borders become more ephemeral, partly due to the global reach of the media. The Internet has made jokes shorter, more visual, and less dependent on language, while some important differences adjusted to the local social-cultural context remain.

Liisi Laineste (b. 1978), PhD, Estonian Literary Museum, Department of Folkloristics, Senior Researcher (Vanemuise 42, 51003 Tartu), liisi@folklore.ee

Anastasiya Fiadotava (b. 1991), MA, University of Tartu, Institute of Cultural Research, doctoral student; Estonian Literary Museum, Department of Folkloristics, Junior Researcher (Vanemuise 42, 51003 Tartu), anastasiya.fiadotava@folklore.ee 